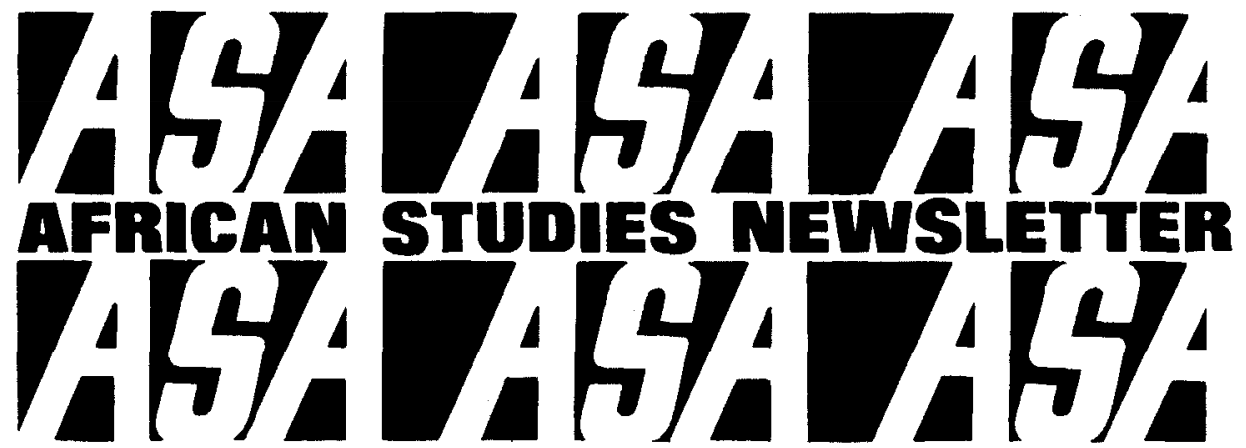

\title{
CONTENTS
}

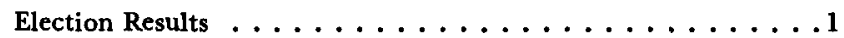

Nominations for ASA Board of Directors . . . . . . . . . 1

ASA Board Members (1979) . . . . . . . . . . . . 2

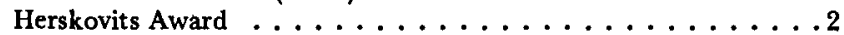

Minutes/Annual Business Meeting .............. . . . . . . . . . . .

Annual Report/African Studies Review . . . . . . . . . . . 3

Minutes

Archives-Libraries Committee Meeting . . . . . . . 6

Committee on Current Issues .............. 8

Cooperative Africana Microform Project ..........

List of Tentative Panels for 22nd Annual Meeting . . . . . . 13

Information for Researchers/Tanzania . . . . . . . . . . 14

Papers Presented at the 21st Annual Meeting . . . . . . . . 16

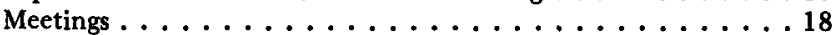

ASA Financial Statement ................ 20

Letter/Book Exhibits-Baltimore . . . . . . . . . . . 21

Special Announcements ................... 22

Grants \& Awards . . . . . . . . . . . . . . . . . . . . . . . . . . . . . . . . 24

Letter/Employment Opportunities for Africanists . . . . . . 25

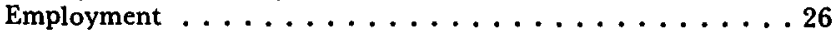

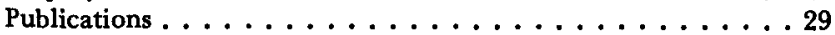

\section{ELECTION RESULTS}

The results of the 1978 elections for Vice President and members of the Board of Directors of the African Studies Association are:

Elected for Vice President: Peter Gutkind

Elected for Board of Directors: Victor Olorunsola

Diann Painter

William Pruitt

\section{NOMINATIONS FOR A.S.A. BOARD OF DIRECTORS 1979}

The Nominating Committee (Ali Mazrui (Chairperson), Richard Sklar, B. Marie Perinbam, Lansine Kaba, W.A.E. Skurnik, Edward I. Steinhart, and Jean Borgatti) met on November 2, 1978. The following people have accepted the nomination of the Committee to stand for election to the Vice Presidency and the Board of Directors:

Vice President: Responses not yet received 